\title{
Plant BiP gene family: differential expression, stress induction and protective role against physiological stresses
}

\author{
Sonia Madali Boseja Carolino, Juliana Rocha Vaez, André Southernman Teixeira Irsigler, Maria Anete S. \\ Valente, Leonardo Augusto Zebral Rodrigues and Elizabeth Pacheco Batista Fontes
}

\author{
Departamento de Bioquímica e Biologia Molecular/BIOAGRO, Universidade Federal de Viçosa, 36571-000, Viçosa, MG, Brasil. \\ *Corresponding author: bbfontes@ufv.br \\ Received: 14/03/2003, Accepted: 08/05/2003
}

In contrast to yeast or mammalian counterpart, BiP (Binding Protein) from several plant species, such as maize, tobacco, Arabidopsis and soybean, is encoded by a multigene family. A systematic characterization and analysis of soybean BiP expression have provided evidence for the existence of multiple, complex regulatory mechanisms controlling plant BiP gene expression. In support of this observation, the soybean $B i P$ gene family has been shown to exhibit organ-specific expression and differential regulation in response to abiotic stresses through distinct signaling pathways. As a member of the stress-regulated HSP70 family of protein, the elucidation of plant BiP function and regulation is likely to lead do new strategies to enhance crop tolerance to environmental stress. Consistent with this observation, transgenic plants overexpressing soybean BiP have demonstrated to exhibit increased tolerance to ER (endoplasmic reticulum) stressors during seed germination and enhanced tolerance to water deficit during plant growth.

Key words: endoplasmic reticulum, ER stressors, Grp78, molecular chaperone, unfolded protein response, water stress.

Família gênica BiP em plantas: expressão diferencial, indução de estresse e papel de proteção contra estresses fisiológicos: Enquanto, em mamíferos e leveduras, a proteína Binding Protein (BiP) é representada por um único gene, em diversas plantas, tais como milho, Arabidopsis, tabaco e soja, a BiP é codificada por uma família multigênica. A análise e a caracterização sistemáticas da expressão de $B i P$ de soja têm revelado a existência de múltiplos mecanismos complexos de regulação que controlam a expressão dos genes $B i P$ de plantas. Consistente com essa observação, tem-se demonstrado que a família de BiP de soja exibe expressão órgão-específica e regulação diferencial em resposta a estresses fisiológicos mediante vias distintas de sinalização intracelular. Como um membro da família Hsp70 de proteínas relacionadas com estresses, a elucidação da função e regulação de $\mathrm{BiP}$ de plantas, provavelmente, resultará no desenvolvimento de novas estratégias moleculares para obtenção de plantas tolerantes a condições de estresses do meio ambiente. Coerente com essa observação, tem-se provado que a hiperexpressão de um gene $B i P$ da soja em plantas transgênicas promove aumento de tolerância a agentes que causam estresses típicos do retículo endoplasmático durante germinação da semente e confere tolerância a estresse hídrico durante o crescimento da planta.

Palavras-chave: chaperona molecular, estresse hídrico, Grp78, inibição de glicosilação, via de resposta a proteínas anormais, retículo endoplasmático.

\section{INTRODUCTION}

The endoplasmic reticulum (ER) processing apparatus comprises a set of molecular chaperones and folding enzymes, which associates with newly synthesized polypeptides to assist proper folding and assembly of oligomeric secretory proteins (for reviews see Pelham, 1989; Hammond and Helenius, 1995; Galili et al., 1998; Vitale and Denecke, 1999). The binding protein $(\mathrm{BiP})$ represents one of the best-characterized molecular chaperones from the ER and is also designated GRP78 (Glucose regulated protein-78 kDa). In mammalian cells, BiP has been shown to play a dynamic role in the regulation of various ER-supported processes, including regulation of eIF-2 kinase and mRNA translation, regulation of its own expression, catalysis of protein folding and targeting 
of misfolded proteins for degradation (Hammond and Helenius, 1995; Morris et al., 1997; Laitusis et al., 1999; Liu et al., 2002; Ma et al., 2002). Here, we primarily focus on the characterization of $\mathrm{BiP}$ induction, regulation and protective properties against physiological stresses in higher plants. We also emphasize the conservation and divergence of plant $\mathrm{BiP}$ regulation and function as compared to the yeast and mammalian counterpart.

\section{ER stress regulation of plant BiP genes}

As a member of the stress-regulated HSP70 family of proteins, the expression of $B i P / G R P 78$ genes has been examined primarily under stress conditions that promote upregulation of $B i P$ mRNA (reviewed in Lee, 2001). The most characterized signaling event that induces BiP is the accumulation of unfolded proteins in the ER caused by ER stressors, like tunicamycin that inhibits N-glycosylation of newly synthesized proteins, or by expression of folding-defective mutant secretory proteins (reviewed in Lee, 1992). This induction is achieved through a signaling pathway named the unfolded protein response pathway (UPR), which coordinately up-regulates the transcription of a set of ER-resident proteins, including the molecular chaperone BiP (Lee, 2001).

In plants, like in mammals and yeast, the expression of $B i P$ is regulated according to cellular requirements for chaperone activity. Thus, both increase of secretory activity and accumulation of unfolded proteins within the ER result in the induction of BiP synthesis in plants (reviewed in Boston et al., 1996; Pedrazzini and Vitale, 1996). In the floury-2 mutant of maize, the synthesis of a zein-like storage protein variant, which contains an uncleavable signal sequence, is associated with increased accumulation of BiP (Boston et al., 1991; Fontes et al., 1991; Coleman et al., 1995; Gillinkin et al., 1997). Expression of an assembly-defective mutant of the bean storage protein phaseolin also induces BiP synthesis in tobacco leaf protoplasts (Pedrazzinni et al., 1994). Furthermore, tunicamycin, a potent activator of the UPR pathway, efficiently induces $B i P$ expression at both mRNA and protein level in several plant systems (Fontes et al., 1991; D'amico et al., 1992; Koizumi, 1996). Recently, we have isolated and fused soybean $B i P$ promoters to the reporter gene GUS and we have shown that tunicamycin treatment up regulates soybean $\mathrm{BiP}$ promoters in transgenic tobacco (Buzeli et al., 2002). Collectively, these results have led to the conclusion that, like mammal and yeast BiP, plant $B i P$ is most likely regulated through an unfolded protein response pathway. This idea is supported by the observation that, like in mammalian cells, overexpression of $B i P$ in tobacco leaf protoplasts attenuates ER stress caused by tunicamycin and prevents activation of the unfolded protein response pathway (Leborgne-Castel et al., 1999). The UPR signaling pathway has been characterized in details in Saccharomyces cerevisiae and mammalian cells.

In yeast, the UPR signaling cascade involves an ER transmembrane kinase Ire $1 \mathrm{p}$ and a basic-leucine zipper transcription factor, Hac1p (Mori et al., 1993; Cox and Walter, 1996). The activity of Haclp is controlled by regulated splicing of its mRNA through a spliceosome independent pathway, involving tRNA ligase and the endonuclease activity of Ire1p (Sidrauski et al., 1996; Sidrauski and Walter, 1997). Hac1p binds to the UPR-dependent cis-acting element (UPRE) on target gene promoters to activate their transcription (Mori et al., 1992; Cox and Walter, 1996).

Two mammalian homologs of Irel were identified in mice and humans and both exhibited endoribonuclease activity (for review, see Kaufman, 1999). Overexpression of Ire $1 p$ activates the UPR pathway in an Ire1p endoribonuclease activity-dependent manner (Tirasophon et al., 1998). This argues favorably for the existence of an Ire1p-dependent pathway for UPR induction in mammalian cells. In fact, the transcription factor XBP-1, which is activated by an ER stressinduced splicing event performed by Ire1, binds to UPRspecific targets to activate transcription (Yoshida et al., 2001). Nevertheless, genetic disruption of both IRE 1 alleles in mice had no effect in the UPR pathway (Urano et al., 2000). An alternative Ire $1 \mathrm{p}$-independent pathway to activate $\mathrm{BiP}$ genes in response to ER stress has also been described in mammalian cells (for review, see Lee, 2001). In this signaling pathway, the activation of $B i P$ promoters is dependent on the ER-stress induced proteolysis of the ER transmembrane protein ATF6 (Yoshida et al., 1998; Chen et al., 2002). This allows the cytoplasmic bZIP domain of ATF6 to move to the nucleus, where it can bind to ERSE (ER stress response element) cisregulatory elements with the transcription factor NF-Y and activate expression of target genes such as BiP (Yoshida et al., 2001). Three independent sequence motifs, UPRE (through XBP-1 binding), ERSEI and ERSEII (through ATF6 binding), have been shown to confer the ER stress activation of mammalian promoters (Yoshida et al., 1998; Roy and Lee, 1999; Kokame et al., 2001, Okada et al., 2002).

With respect to plant cells, two Ire1 homologs (AtIre 1-1 and AtIre1-2) have been identified in Arabidopsis and one in 
rice (OsIre1) (Koizumi et al., 2001; Okushima et al., 2002). The modular organization of these putative ERtransmembrane receptors includes four domains characteristic of Ire1 proteins found in mammals and yeast: (1) a lumenal sensing domain at the $\mathrm{N}$-terminal region, (2) a transmembrane domain, (3) a protein kinase domain and (4) a ribonuclease domain at the $\mathrm{C}$-terminal end. Furthermore, the Ire1-1 protein from Arabidopsis protein functions as a protein kinase and the sensor domain of AtIre1-1 and AtIre1-2 when linked to the C-terminal domain of yeast Ire1 functionally complement a yeast $\Delta$ irel mutant (Koizumi et al., 2001). Nevertheless, homologs of ATF6 or hac1/XBP-1 have not been found in the Arabidopsis genome and the downstream components of the plant UPR remain to be identified.

Recently, microarray hybridization experiments revealed several UPR target genes in Arabidopsis involved in ER and secretory pathway functions (Martinez and Chrispeels, 2003). These genomic analyses suggested that, like in mammalian cells, plant cells have evolved at least three different mechanisms that mediate UPR: (1) transcriptional induction of genes encoding chaperones and vesicle trafficking proteins; (2) attenuation of genes that encode secretory proteins; (3) upregulation of the ER-associated protein degradation (ERAD) system for rapid cleaning of unfolded proteins in the ER.

\section{Tissue-specific expression of plant BiP genes}

The expression of plant BiP has also been shown to be also under tissue-specific and developmental regulation (reviewed in Boston et al., 1996; Pedrazzini and Vitale, 1996; Galili et al., 1998). Tobacco BiP transcripts accumulate predominantly in flower organs that contain secretory tissues and in tissues with high proportions of rapidly dividing cells (Denecke et al., 1991). In soybean, the members of the BiP gene family are under differential organ-specific regulation (Cascardo et al., 2001) and the expression of BiP genes is regulated by developmental events that are associated with high cellular secretory activity (Kalinski et al., 1995; Fontes et al., 1996). Likewise, in maize, rice and wheat endosperms (Boston et al., 1991; Fontes et al., 1991; Muench et al., 1997; DuPont et al., 1998) and in pumpkin cotyledons (Hatano et al., 1997), the synthesis of BiP is coordinated with the onset of active storage protein. Therefore, the synthesis of $\mathrm{BiP}$ is also induced by developmental events associated with high cellular secretory activity. Accordingly, soybean BiP promoters have demonstrated to drive high levels of GUS reporter gene expression in tissues with elevated secretory activity, such as leaf trichome and vascular tissues (Buzeli et al., 2002). Histochemical GUS assays of transgenic plants also displayed an intense staining in tissues with high rate of cell division, such as the apical meristems from roots and shoots and the procambial regions. Following the process of cell division, meristematic cells exhibit high secretory activity associated with the biogenesis of the plant cell wall.

Plant $B i P$ promoters share conserved structural features with mammalian $B i P$ promoters, containing multiple copies of CCAAT box-like motifs flanked by CG-rich sequences. These are required for high level of basal expression and constitute repetitive units of the ER stress response element (Lee, 2001). Promoter deletion analyses, using 5 'flanking sequences of a soybean $B i P(g s B i P 6)$ gene fused to glucuronidase (GUS) reporter genes, identified two cis-regulatory functional domains that are important for the spatially-regulated activation of BiP expression under normal plant development (Buzeli et al., 2002). The first one, designated cis-acting regulatory domain 1, CRD1 (-358 to -211 , on gs BiP6), corresponds to an AT-rich enhancer-like sequence that activates expression of the BiP minimal promoter in all organs analyzed. A second activating domain, CRD2 (-211 to -80$)$, however, is required for $B i P$ promoter activity in meristematic tissues and phloem cells. Apparently, the CRD2 sequence also harbors negative cis-acting elements, because removal of this region caused derepression of the gsBiP6 promoter in parenchymatic xylem rays (Buzeli et al., 2002).

The CRD2 region may also confer the ER stress activation of plant $B i P$ promoters because its removal suppresses reporter gene induction by tunicamycin (Buzeli et al., 2002). The CRD2 sequence harbors closely related ERSE-I and ERSE-II-like sequences as well as several potential cis-regulatory elements found in plant promoters, such as G-box-related sequences and auxin-responsive elements (Ingram and Bartels, 1996; Guilfoyle et al., 1998). The structural organization of CRD2 in plant $B i P$ promoters with multiple putative cis-acting elements accommodates the argument that they may act as composite/coupling elements that function in different combinations to confer a diversity of tissue-specific, developmental and stress-regulated patterns.

\section{Members of the soybean BiP family display differential pattern of expression}

The genome of several plant species, such as maize, tobacco, Arabidopsis and soybean, is represented by multiple copies of BiP genes (Denecke et al., 1991; Kalinski et al., 
1995; Wrobel et al., 1997; Sung et al., 2001). This observation has raised the possibility that individual members of the plant $B i P$ gene family exhibit differential regulation, function or substrate specificity. Nevertheless, in maize, two BiP genes isolated from a kernel cDNA library have been shown to exhibit similar pattern of expression (Wrobel et al., 1997). Likewise, three $B i P$ genes from tobacco or two $B i P$ genes (BiP-1 and BiP-2) from Arabidopsis have been shown to be coordinately regulated (Denecke et al., 1991; Sung et al., 2001). These analyses of gene expression, however, did not cover entirely the complexity of the maize, tobacco or Arabidopsis BiP family and, thus, it remains possible that as yet uncharacterized $B i P$ genes in these plant species are regulated differently to those characterized genes. This was found to be the case for the soybean BiP gene family, which has been shown to be under organ-specific regulation (Cascardo et al., 2001). In fact, the two-dimensional gel electrophoresis profiles displayed by the BiP forms from different soybean organs are quite distinct. Furthermore, RTPCR experiments using gene-specific primers established that three of the four isolated soybean BiP genes (soyBiPA, soy $B i P B$, soyBiPC and soyBiPD) are differentially expressed in different organs (Kalinski et al, 1995; Figueiredo et al., 1997; Cascardo et al., 2001). While all four BiP transcripts are detected in leaves by gene-specific RT-PCR assays, different subsets are detected in the other organs (Cascardo et al., 2001). The soyBiPD is expressed in all organs, whereas the expression of the $\operatorname{soy} B i P B$ is restricted to leaves. The soyBiPA transcripts are detected in leaves, roots and seeds and soyBiPC RNA is confined to leaves, seeds and pods. The differential expression of the soybean BiP gene family indicates that plant $B i P$ has evolved independent regulatory mechanisms, possibly to maximize $B i P$ expression according to cellular requirements or under specific stress conditions, which are sensed differently by distinct plant organs. Alternatively, these results might be correlated with distinct functions or substrate specificity of the individual members of the family.

\section{Plant BiP genes respond to physiological stresses through distinct signaling pathways}

Plant $B i P$ expression has also been shown to respond to a variety of abiotic and biotic stress conditions, such as water stress, fungus infestation, insect attack, nutritional stress, cold acclimation and elicitors of the plant-pathogenesis response (Anderson et al., 1994; Kalinski et al., 1995; Fontes et al., 1996; Figueiredo et al., 1997; Fontes et al., 1999; Picoli et al., 2001). However, in some plant species, specific stress conditions and developmental events alter BiP mRNA and protein levels to different extents, suggesting that posttranscriptional mechanisms are also involved in the regulation of BiP synthesis in plants (Anderson et al., 1994; Kalinski et al., 1995). Alternatively or additionally, these discrepancies between the level of BiP mRNA and protein may reflect differential expression and regulation of plant $B i P$ gene families, since the genome of several plant species is represented by multiple BiP genes (Denecke et al., 1991; Kalinski et al., 1995; Wrobel et al., 1997). Consistent with the former hypothesis, the constitutive overexpression of tobacco BiP genes in transgenic plants led to a significant but non-proportional increase in BiP mRNA and protein accumulation (Leborgne-Castel et al., 1999; EPB Fontes, unpublished observations). On the other hand, the observation that the members of the soybean BiP gene family are not coordinately regulated argues in favor of the latter hypothesis (Cascardo et al., 2000; 2001). Both alternatives, however, support the argument that multiple, complex regulatory mechanisms control BiP gene expression in plants.

Several lines of evidence indicate that stimulation of $B i P$ expression by water stress or pathogen attack occurs through a pathway distinct from the UPR signaling cascade. First, although all soybean BiP forms are up-regulated by tunicamycin, only a subset of the soybean $\mathrm{BiP}$ forms is induced by osmotic stress in cell cultures (Cascardo et al, 2000). Similarly, the mRNA levels of all four soyBiP genes are controlled by tunicamycin, but only the soyBiPA RNA is up regulated by osmotic stress. The absence of soyBiPC, soyBiPB and soyBiPD induction in PEG-treated cells suggests that the UPR and water-stress regulated pathways are independently controlled. Second, the rapid induction of BiP by PEG is distinct from the delayed tunicamycin-induction kinetics (Cascardo et al., 2000). Likewise, in tobacco leaves, the kinetics of $B i P$ induction by cell wall degrading enzymes (CDEs) treatment, which mimics bacterial pathogen attack, is distinct from that of UPR (Jelitto-Van Dooren et al., 1999). The difference in the kinetics of BiP induction suggests that different components from the UPR pathway are involved in the signaling pathway that regulates $B i P$ expression under osmotic stress and by CDE response. Finally, treatment of soybean suspension cell culture with both PEG and tunicamycin promoted a synergistic effect on the level of BiP induction (Cascardo et al., 2000). Similarly, in tobacco protoplasts, the BiP inductions by CDE response and UPR are additive (Jelitto-Van Dooren et al., 1999). Taken together, 
these results support the notion that the regulation of $B i P$ expression by physiological stresses functions in distinct signal transduction pathways. It will be interesting to know whether induction of BiP by osmotic stress and elicitors of the plant-pathogenesis response occurs by similar and overlapping signaling cascades.

\section{Stress-induced phosphorylation state and oligomerization of soybean BiP}

Plant BiP exists in interconvertible phosphorylated and non-phosphorylated forms and the equilibrium can be shift to either direction in response to different stimuli (Cascardo et al., 2000). In contrast to tunicamycin treatment, water stress condition stimulated phosphorylation of $\mathrm{BiP}$ species in soybean cultured cells and stressed leaves (Cascardo et al., 2000). Although the tunicamycin-induced BiP forms are unmodified and osmotic stress-induced $\mathrm{BiP}$ forms are phosphorylated, both treatments cause the conversion of oligomeric BiP to the monomeric forms (Carolino et al., 2001). In mammalian cells, modification of $\mathrm{BiP}$ is associated with its oligomerization (Freiden et al., 1992). Thus, the modification of plant $\mathrm{BiP}$ protein in response to water stress differs from the usual pattern of post-translational modifications of eukaryotic BiPs. The simplest explanation for these results is that phosphorylation of soybean BiP by osmotic stress may serve as a distinct regulatory function and, since is not restricted to the oligomeric form of BiP, it may occur at different sites. The determination of the phosphorylation sites of normal and PEG-induced BiP forms is required to validate this interpretation.

In animal cells, tunicamycin-induced $\mathrm{BiP}$ or $\mathrm{BiP}$ bound to nascent proteins is unmodified and it is generally accepted that the non-phosphorylated form is the biologically active BiP species in the folding pathway (Carlsson and Lazarides, 1983; Hendershot et al., 1988; Freiden et al., 1992). Despite their phosphorylation state, soybean $\mathrm{BiP}$ isoforms from waterstressed leaves exhibit protein-binding activity and associates with a water stress-induced $28 \mathrm{kDa}$ polypeptide (Cascardo et al., 2000). Two lines of evidence suggest that the association between $\mathrm{BiP}$ and the $28 \mathrm{kDa}$ water stress-induced polypeptide is not an in-vitro artifact and may be physiologically relevant. First, the $28 \mathrm{kDa}$ polypeptide was localized in microsomal membranes composed primarily of endomembrane vesicles derived from the ER, Golgi and tonoplast. As a secretory protein, the $28 \mathrm{kDa}$ polypeptide is expected to be transiently co-localized with BiP, as it enters the ER. Second, the complex
BiP: $28 \mathrm{kDa}$ polypeptide was sensitive to ATP, a property of chaperone-mediated interactions. Therefore, phosphorylation of $\mathrm{BiP}$ by osmotic stress cannot be attributed simply to inactivation of induced $\mathrm{BiP}$ isoforms. These observations suggest that plant BiP functional regulation may differ from other eukaryotic BiPs.

\section{Protective properties of plant $\mathrm{BiP}$ against abiotic stresses}

Since these UPR-induced proteins have been shown to act as chaperones, they are believed to function in an ER protective mechanism against protein misaggregation. In fact, overexpression of $\mathrm{BiP}$ in mammalian cultured cells (Morris et al., 1997) and tobacco protoplasts (Leborgne-Castel et al., 1999) prevents the induction of UPR-induced genes and increases cell tolerance to stress, suggesting that BiP directly alleviates the ER stress. Furthermore, transfection of mammalian cultured cells with

$B i P$ antisense mRNA expression constructs suppressed the induction of $B i P$ without altering basal BiP levels. These cells also showed increased sensitivity to ionophores (Li and Lee, 1991; Li et al., 1992), oxidative stress (Gomer et al., 1991), and cell-mediated toxicity (Sugawara et al., 1993).

The protective role of plant $\mathrm{BiP}$ against abiotic stresses has also been examined at the whole plant level (Alvim et al., 2001). The effect of BiP overexpression on a typical ER stress response has been investigated using a germination/ survival assay in the presence of tunicamycin, a potent activator of the UPR pathway. For this assay, soybean seeds are allowed to germinate for 5 days in a solid MS-based medium supplemented with $5 \mu \mathrm{g} \cdot \mathrm{mL}^{-1}$ of tunicamycin and then transferred to a tunicamycin-free medium. The tunicamycin-tolerant germination phenotype is interpreted as the capacity of the seed to recover and germinate into seedlings. Transgenic seeds expressing the soybean $B i P$ gene recover after removing tunicamycin whereas those lacking the transgene fail to germinate and eventually die (Alvim et al., 2001). Like in mammalian cells, in plants the BiPmediated protection against ER stressors has been shown to be due to restoration of the protein synthetic capability under ER stress conditions (Morris et al., 1997; Laitusis et al., 1999; Leborgne-Castel et al., 1999; Alvim et al., 2001).

In addition to alleviate ER stress, overexpression of plant $B i P$ has also been shown to increase tolerance of plants to water deficit (Figueiredo et al., 1997, Cascardo et al., 2000, Alvim et al., 2001). Although the mechanism of BiP-mediated water stress tolerance has yet to be elucidate, the water-stress 
stimulation of the antioxidative defenses was not observed in droughted sense leaves, suggesting that overexpression of $B i P$ in plants may prevent endogenous oxidative stress.

\section{CONCLUSION}

Although the overall ER-stress response in plants is thought to be similar to that of yeast and mammals, compelling evidence in the literature suggests that the $B i P$ stress response may differ significantly in plants. We have described several key differences in the expression and regulation of the ERmolecular chaperone soybean BiP under abiotic stress. These differences may be related to the existence of multiple $B i P$ genes in plants and to the unique challenge that stress conditions represent to plants compared to other eukaryotes. Because plants cannot avoid environmental changes, they are constantly subjected to a variety of stress conditions. Acclimation to environmental changes requires responses against cell damages, such as preservation of membrane and protein structures, which enable the plant to tolerate and minimize the deleterious effect of abiotic stress. Possibly the members of the plant $B i P$ gene family have evolved independent regulatory mechanisms to ensure a high level of expression under a broad range of biotic and abiotic stress conditions to protect the plant against cell damage. Thus, the effectiveness of $B i P$ overexpression on plant protection against stresses may be related to its induction by a large variety of physiological stress conditions.

Acknowledgments: We are grateful to the financial support from the Brazilian Government Agency, PADCT/CNPq Grant 62.0272/97.0 (to E.P.B.F.) and FAPEMIG Grant CBB 333/ 01 (to E.P.B.F.). SMBC was supported by a CNPq posdoctoral fellowship, JRV and ASTI by a CNPq graduate fellowship, LAZR by a CNPq undergraduate scholarship, and MASV by a CAPES graduate fellowship from the Brazilian Government.

\section{REFERENCES}

Alvim FC, Carolino SMB, Cascardo JCM, Nunes CC, Martinez CA, Otoni WC, Fontes EPB (2001) Enhanced accumulation of $\mathrm{BiP}$ in transgenic plants confers tolerance to water stress. Plant Physiol. 126:1042-1054.

Anderson JV, Li QB, Haskell DW, Guy CL (1994) Structural organization of the spinach endoplasmic reticulumluminal 70-kilodalton heat-shock cognate gene and expression of 70-kilodalton heat-shock genes during cold acclimation. Plant Physiol. 104:1395-1370.
Boston RS, Viitanen PV, Vierling E (1996) Molecular chaperones and protein folding in the plants. Plant Mol. Biol. 34:191-222.

Boston RS, Fontes EPB, Shank BB, Wrobel RL (1991) Increased expression of the maize immunoglobulin binding protein homolog b-70 in three zein regulatory mutants. Plant Cell 3:497-505.

Buzeli RAA, Cascardo JCM, Rodrigues LAZ, Andrade MO, Loureiro ME, Otoni WC, Fontes EPB (2002) Tissuespecific regulation of Bip/Grp78 genes: a cis-acting regulatory domain is required for $\mathrm{B} i P$ promoter activity in plant meristems. Plant Mol. Biol. 50:757-771.

Carlsson L, Lazarides E (1983) ADP-ribosylation of the $\mathrm{Mr}$ 83,000 stress-inducible and glucose-regulated protein in avian and mammalian cells: modulation by heat shock and glucose starvation. Proc. Natl. Acad. Sci. USA 80:4664-4668.

Carolino SMB, Fontes EPB (2001) Interconversion of monomeric andoligomeric forms of Soybean BiP under normal and stress conditions. In: Annals of the VIII Reunião Brasileira de Fisiologia Vegetal. Ilhéus, Brasil, pp. $865(1-3)$.

Cascardo JCM, Almeida RS, Buzeli RAA, Carolino SMB, Otoni WC, Fontes EPB (2000) The phosphorylation state and expression of soybean BiP isoforms are differentially regulated following abiotic stresses. J. Biol. Chem. 275:14494-14500.

Cascardo JCM, Buzeli RAA, Almeida RS, Otoni WC, Fontes EPB (2001) Differential expression of the soybean BiP gene family. Plant Sci. 160:273-281.

Coleman CE, Lopes MA, Gillikin JW, Boston RS, Larkins BA (1995) A defective signal peptide in the maize highlysine mutant floury-2. Proc. Natl. Acad. Sci. USA 92:6828-6831.

Cox JS, Walter P (1996) A novel mechanism for regulating activity of a transcription factor that controls the unfolded protein response. Cell 87:391-404.

Chen X, Shen J, Prywes R. (2002) The luminal domain of ATF6 senses endoplasmic reticulum (ER) stress and causes translocation of ATF6 from the ER to the Golgi. J. Biol. Chem. 277:13045-13052.

D'amico L, Valsania B, Daminati MG, Fabrini MS, Nitti G, Bollini R, Ceriotti A, Vitale A (1992) Bean homologues of the mammalian glucose regulated proteins: induction by tunicamycin and interaction with newly-synthesized storage proteins in the endoplasmic reticulum. Plant J. 2:443-445.

Denecke J (1996) Soluble endoplasmic reticulum resident proteins and their function in protein synthesis and transport. Plant Physiol. Biochem. 34:197-205.

Denecke J, Goldman MHS, Demolder J, Seurinck J, Botterman J (1991) The tobacco luminal binding protein is encoded by a multigene family. Plant Cell 3:1025-1035. 
DuPont FM, Hurkman WJ, Tanaka CK, Chan R (1998) BiP, HSP70, NDK and PDI in wheat endosperm: I. Accumulation of mRNA and protein during grain development. Physiol. Plat.103:70-79.

Figueiredo JEF, Cascardo JCM, Carolino SMB, Alvim F, Fontes EPB (1997) Water-stress regulation and molecular analysis of the soybean BiP gene family. Rev. Bras. Fisiol. Veg. 9:103-110.

Fontes MA, Otoni WC, Carolino SMB, Brommonschenkel SH, Fontes EPB, Fári M, Louro RP (1999) Hyperhydricity in pepper plants regenerated in vitro: involvement of $\mathrm{BiP}$ (Binding Protein) and ultrastructural aspects. Plant Cell Rep. 19:81-87.

Fontes EPB, Shank BB, Wrobel RL, Moose SP, O'Brian GR, Wurtzel ET, Boston RS (1991) Characterization of an immunoglobulin binding protein homolog in the maize floury-2 endosperm mutant. Plant Cell 3:483-496.

Fontes EPB, Silva CJ, Carolino SMB, Figueiredo JEF, Batista DPO (1996) A soybean binding protein (BiP) homolog is temporally regulated in soybean seeds and associates detectably with normal storage proteins in vitro. Braz. J. Genet. 19:306-312.

Freiden PJ, Gaut JR, Hendershoot LM (1992) Interconversion of three differentially modified and assembled forms of BiP. EMBO J. 11:63-70.

Galili G, Sengupta-Gopalam C, Ceriotti A (1998) The endoplasmic reticulum of plant cells and its role in protein maturation and biogenesis of oil bodies. Plant Mol. Biol. 38:1-29.

Gillinki JW, Zhang F, Coleman CE, Bass HW, Larkins, BA, Boston RS (1997) A defective signal peptide tethers the floury-2 zein to the endoplasmic reticulum membrane. Plant Physiol. 114:345-352.

Gomer CJ, Ferrario A, Rucker N, Wong S, Lee AS (1991) Glucose regulated protein induction and cellular resistance to oxidative stress mediated by porphyrin photosensitization. Cancer Res. 15:6574-6579.

Guilfoyle T, Hagen G, Ulmasov T, Murfett J (1998) How does auxin turn on genes? Plant Physiol. 118:341-347.

Hammond C, Helenius A (1995). Quality control in the secretory pathway. Curr. Opin. Cell Biol. 7:523-529.

Hatano K, Shimada T, Hiraiwa N, Nishimura M, HaraNishimura I (1997) A rapid increase in the level of binding protein $(\mathrm{BiP})$ is accompanied by synthesis and degradation of storage proteins in pumpkin cotyledons. Plant Cell Physiol. 38:344-351.

Hendershot LM, Ting J, Lee A (1988) Identity of the immunoglobulin heavy-chain-binding protein with the 78,000 dalton glucose-regulated protein and the role of post-translational modification in its binding function. J. Mol. Cell. Biol. 8:4250-4256.
Ingram J, Bartels D (1996) The molecular basis of dehydration in plants. Annu. Rev. Plant Physiol. Plant Mol. Biol. 47:377-403.

Kalinski A, Rowley DL, Loer DS, Foley C, Buta G, Herman EM (1995) Binding-protein expression is subject to temporal, developmental and stress-induced regulation in terminally differential soybean organs. Planta 195:611-621.

Kaufman R (1999) Stress signaling from the lumen of the endoplasmic reticulum: coordination of gene transcriptional and translational controls. Gene Dev. 13:1211-1233.

Kokame K, Kato H, Miyata T (2001) Identification of ERSEII, a new cis-acting element responsible for the ATF6dependent mammalian unfolded response. J. Biol. Chem. 276:9199-9205.

Koizumi N (1996) Isolation and responses to stress of a gene that encodes a luminal binding protein in Arabidopsis thaliana. Plant Cell Physiol. 37:862-865.

Koizumi N, Martinez IM, Kimata Y, Kohno K, Sano H , Chrispeels MJ (2001) Molecular characterization of two Arabidopsis Ire1 homologs, endoplasmic reticulumlocated transmembrane protein kinase. Plant Physiol. 127:949-962.

Jelitto-Van Dooren EPWM, Vidal S, Denecke J (1999) Antecipating endoplasmic reticulum stress: a novel early response before phatogenesis-related gene induction. Plant Cell 11:1935-1943.

Laitusis AL, Brostrom MA, Brostrom CO (1999) The dynamic role of GRP78/BiP in the coordination of mRNA translation with protein processing. J. Biol. Chem. 274:486-493.

Leborgne-Castel N, Jelitto-Van Dooren EPWM, Crofts AJ, Denecke J (1999) Overexpression of BiP in tobacco alleviates endoplasmic reticulum stress. Plant Cell 11:459-469.

Lee AS (1992) Mammalian stress response: induction of the glucose-regulated protein family. Curr. Opin. Cell Biol. 4:267-273.

Lee AS (2001) The glucose-regulated proteins: stress induction and clinical applications. TIBS 26:504-510.

Li XA, Lee AS (1991) Competitive inhibition of a set of endoplasmic reticulum protein genes (GRP78, GRP94 and Erp72) retards cell growth and lowers viability after ionophore treatment. Mol. Cell. Biol. 11:3446-3453.

Li LJ, Li XA, Ferrario A, Rucker N, Liu ES, Wong S, Gomer CJ, Lee AS (1992) Establishment of a Chinese hamster ovary cell line that expresses grp78 antisense transcripts and suppresses A23187 induction of both GRP78 and GRP94. J. Cell Physiol. 153:575-582. 
Liu CY, Wong HN, Schauerte JA, Kaufman RJ (2002) The protein kinase/endoribonuclease IRE1 $\alpha$ that signals the unfolded protein response has a luminal N-terminal ligandindependent dimerization domain J. Biol. Chem. 277:18346-18356.

Ma K, Vattem KM, Wek RC (2002) Dimerization and release of molecular chaperone inhibition facilitate activation of eukaryotic initiation factor-2 kinase in response to endoplasmic reticulum stress. J. Biol. Chem. 277:1872818735.

Martinez IM, Chrispeels MJ (2003) Genomic analysis of the unfolded protein response in

Arabidopsis shows its connection to important cellular processes. Plant Cell 15:561-576.

Mori K, Sant A, Kohono K, Normington K, Gething M.-J, Sambrook JF (1992) A 22 bp cis-acting element is necessary and sufficient for the induction of the yeast $K A R 2$ (BiP) gene by unfolded proteins. EMBO J. 11:2583-2593.

Mori K, Ma W, Gething M.-J, Sambrook JF (1993) A transmembrane protein with a cdc2+/CDC28-related kinase activity is required for signaling from the ER to the nucleus. Cell 74:743-756.

Morris JA, Dorner AJ, Edwards CA, Hendershot LM, Kaufman J (1997) Immunoglobulin binding protein (BiP) function is required to protect cells from endoplasmic reticulum stress but is not required for the secretion of selective proteins. J. Biol. Chem. 272:4327-4334.

Muench DG, Wu Y, Zhang Y, Li X, Boston RS, Okita TW (1997) Molecular cloning, expression and subcelullar localization of a BiP homolog from rice endosperm tissue. Plant Cell Physiol. 38:404-412.

Okada T, Yoshida H, Akezawa R, Negishi M, Mori K (2002) Distinct roles of ATF6 and PERK in transcription during mammalian unfolded protein response. Biochem. J. 366:585-594.

Okushima Y, Koizumi N, Yamaguchi Y, Kimata Y, Kohno K, Sano H (2002) Isolation and characterization of a putative transducer of endoplasmic reticulum stress in Oryza sativa. Plant Cell Physiol. 43:532-539.

Pedrazzini E, Giovinazzo G, Bollini R, Ceriotti A, Vitale A (1994) Binding of BiP to an assembly-defective protein in plant cells. Plant J. 5:103-110.

Pedrazzini A, Vitale A (1996) The binding protein (BiP) and the synthesis of secretory proteins. Plant Phisiol. Biochem. 34, 207-216.

Pelham HRB (1989). Control of protein exit from the endoplasmic reticulum. Ann. Rev. Cell Biol. 5:1-23.
Picoli EAT, Figueira ML, Otoni WC, Carolino SMB, Almeida RS, Silva EAM, Carvalho CR, Fontes EPB (2001) Hyperhydricity in in vitro eggplant regenerated plants: structural characteristics and involvement of BiP (Binding Protein). Plant Sci. 160:857-868.

Roy B, Lee AS (1999) The mammalian endoplasmic reticulum stress response element consits of an evolutionarily conserved tripartite structure and interacts with a novel stress-inducible complex. Nucleic Acids Res. 27:14371443.

Sidrauski C, Cox JS, Walter P (1996) tRNA ligase is required for regulated mRNA splicing in the unfolded protein response. Cell 87:405-413.

Sidrauski C, Walter P (1997) The transmembrane kinase Ire $1 p$ is a site-specific endonuclease that initiates mRNA splicing in the unfolded protein response. Cell 90:1031-1039.

Sugawara S, Takeda K, Lee AS, Dennert G (1993) Suppression of stress protein GRP78 induction in tumor $\mathrm{B} / \mathrm{C} 10 \mathrm{ME}$ eliminates resistance to cell mediated cytotoxicity. Cancer Res. 53:6001-6005.

Sung DY, Vierling E, Guy CL (2001) Comprehensive expression profile analysis of the Arabidopsis Hsp70 gene family. Plant Physiol. 126:789-800.

Tirasophon W, Welihinda AA, Kaufman RJ (1998) A stress response pathway from the endoplasmic reticulum to the nucleus a novel bifunctional protein kinase/ endoribonuclease (Ire1p) in mammalian cells. Genes Dev. 12:1812-1824.

Urano F, Wang X, Bertolotti A, Ron D (2000) IRE1 and efferent signaling from the endoplasmic reticulum. J. Cell Sci. 113:3697-3702.

Vitale A, Denecke J (1999) The endoplasmic reticulum: gateway of the secretory pathway. Plant Cell 11:615-628.

Yoshida H, Haze K, Yanagi H, Yura T, Mori K (1998) Identification of the cis-acting endoplasmic reticulum stress response element responsible for transcriptional induction of mammalian glucose-regulated proteins. Involvement of basic leucine zipper transcription factors. J. Biol. Chem. 273:33741-33747.

Yoshida H, Okada T, Haze K, Yanagi H, Yura T, Negishi M, Mori K (2001) Endoplasmic reticulum-stress induced formation of transcription factor complex ERSF including NF-Y (CBF) and activating transcription factors $6 \alpha$ and $6 \beta$ that activates the mammalian unfolded protein response. Mol. Cell. Biol. 21:1239-1248.

Wrobel RL, O'Brian GR, Boston RS (1997) Comparative analysis of $\mathrm{BiP}$ gene expression in maize endosperm. Gene 204:105-113. 